\title{
PENGARUH UKURAN PERUSAHAAN, STRUKTUR MODAL, LIKUIDITAS, INVESTMENT OPPORTUNITY SET (IOS), DAN PROFITABILITAS TERHADAP KUALITAS LABA \\ (Perusahaan Makanan dan Minuman yang Terdaftar di Bursa Efek Indonesia Tahun 2013-2017)
}

\author{
Mohamad Zulman ${ }^{(1)}$ dan Dirvi Surya Abbas ${ }^{(2)}$ \\ Universitas Muhammadiyah Tangerang \\ zulman.hakim@umt.ac.id ${ }^{(\mathbf{1})}$ \\ abbas.dirvi@gmail.com ${ }^{(2)}$
}

Tujuan dari penelitian ini untuk mengetahui pengaruh Profitabilitas yang di proksikan dengan Ukuran Perusahaan, Struktur Modal, Likuiditas, Investment Opportunity Set (Ios), Dan Profitabilitas Terhadap Kualitas Laba pada Perusahaan Makanan dan Minuman yang Terdaftar di Bursa Efek Indonesia (BEI). Periode waktu penelitian yang digunakan adalah 5 tahun yaitu periode 2013-2017.

Populasi penelitian ini meliputi seluruh perusahaan makanan dan minuman yang terdaftar di Bursa Efek Indonesia (BEI) periode 2015-2017. Teknik pengambilan sampel menggunakan teknik purposive sampling. Berdasarkan kriteria yang telah ditetapkan diperoleh 7 perusahaan. Jenis data yang digunakan adalah data sekunder yang diperoleh dari situs Bursa Efek Indonesia. Metode analisis yang digunakan adalah analisis regresi data panel.

Hasil penelitian menunjukan bahwa secara parsial Ukuran Perusahaan yang di proksikan logaritma natural (Ln) dari total asset berpengaruh negatif tidak signifikan terhadap kualitas laba. Lalu, Struktur Modal yang diproksikan oleh leverage, dan Investment Opportunity Set (IOS) yang diproksikan dengan market value to book value of assets berpengaruh positif tidak signifikan terhadap Kualitas Laba. Namun, Likuiditas yang diproksikan oleh current ratio berpengaruh positif signifikan terhadap Kualitas Laba.

Keywords: Ukuran Perusahaan, Struktur Modal, Likuiditas, Investment Opportunity Set (IOS), Profitabilitas dan Kualitas Laba

\section{PENDAHULUAN}

Pentingnya informasi laba bagi para penggunanya menjadikan tiap perusahaan berlomba - lomba meningkatkan labanya. Namun, bagi pihak tertentu ada yang melakukan cara tidak sehat guna mencapai tujuan individunya terhadap informasi laba perusahaan. Hal ini yang menjadikan praktek manipulasi laba pada sekarang ini juga tidak jarang dilakukan oleh manajemen perusahaan yang mengetahui kondisi di dalam perusahaan. Ini bermaksud untuk menarik para investor agar menginvestasikan dananya pada perusahaan mereka. Kejadian ini yang mengakibatkan laba perusahaan yang tidak berkualitas (Irawati; 2012).

Dalam melaksanakan
bisnisnya, suatu perusahaan 
memerlukan tambahan dana yang cukup besar untuk modal. Hal ini berkaitan dengan keputusan pemenuhan dana atau financing decision. Keputusan pemenuhan dana berkaitan dengan dua hal yaitu melalui pinjaman yang berupa utang dan melalui penjualan sekuritas (saham). Berkaitan dengan keputusan pemenuhan dana, maka perlu diperhatikan mengenai ukuran perusahaan. Ukuran perusahaan dapat menentukan baik tidaknya kinerja perusahaan. Investor biasanya lebih memiliki kepercayaan pada perusahaan besar, karena perusahaan besar dianggap mampu untuk terus meningkatkan kinerja perusahaannya dengan berupaya meningkatkan kualitas labanya (Risdawati dan Subowo; 2015). Semakin besar ukuran suatu perusahaan maka semakin banyak mendapat perhatian baik dari para analis, investor maupun pemerintah.

yang $\begin{array}{r}\text { Kualitas } \\ \text { rendah }\end{array}$ (low quality) merupakan sinyal alokasi sumber daya yang kurang baik, sehingga menimbulkan kesalahan dalam pembuatan keputusan para pemakai informasi seperti investor dan kreditor. Adanya tindakan manajemen yang melaporkan laba yang tidak menggambarkan kondisi perusahaan yang sebenarnya mengakibatkan laba yang dihasilkan menjadi diragukan kualitasnya. Fenomena ini dapat merugikan banyak pihak pengguna laporan keuangan. Di Indonesia, permasalahan tentang kredibilitas atas informasi laba sering terjadi sehingga menyebabkan turunnya kepercayaan investor terhadap kualitas laba. Pengukuran terhadap kualitas laba dapat diukur dengan menggunakan earnings response coefficient (ERC). Earnings Response Coefficient (ERC) adalah ukuran besaran abnormal return suatu sekuritas sebagai respon terhadap komponen laba kejutan (unexpected earnings) yang dilaporkan oleh perusahaan yang mengeluarkan sekuritas tersebut (Scott; 2001).

Perusahaan makanan dan minuman merupakan salah satu kategori sektor industry di Bursa Efek Indonesia (BEI) yang mempunyai peluang untuk tumbuh dan berkembang. Industry makanan dan minuman diprediksi akan membaik kondisinya. Hal ini terlihat semakin menjamurnya industri makanan dan minuman di Negara ini khususnya semenjak memasuki krisis berkepanjangan. Kondisi ini membuat persaingan semakin ketat sehingga para manajer perusahaan berlombalomba mencari investor untuk menginvestasikan dananya di perusahaan makanan dan minuman tersebut.

Terdapat beberapa faktor yang mempengaruhi kualitas laba seperti yang sudah diteliti oleh Peneliti sebelumnya yaitu variabel risiko sistematik atau beta, ukuran perusahaan, persistensi laba, pertumbuhan laba, struktur modal, leverage, kualitas tanggung jawab sosial perusahaan, kualitas auditor, likuiditas, kesempatan bertumbuh dan kualitas akrual (Agustina dan Gede; 2017). Dari faktor-faktor yang mempengaruhi kualitas laba, dalam penelitian ini peneliti memilih faktor ukuran perusahaan, struktur modal, likuiditas, dan investment opportunity set sebagai faktor-faktor yang mempengaruhi 
kualitas laba karena adanya hasilhasil penelitian sebelumnya yang belum konsisten.

Selain masalah ketidakkonsistenan beberapa hasil penelitian, alasan dilakukannya penelitian kualitas laba terkait ukuran perusahaan, struktur modal, likuiditas, dan investment opportunity set karena informasi laba merupakan informasi penting bagi investor dalam mengambil keputusan terkait dengan investasi yang akan dilakukan sehingga kualitas informasi laba yang terkandung dalam laporan keuangan perusahaan menjadi perhatian utama (Agustina dan Gede; 2017). Penelitian ini dilakukan pada sektor perusahaan makanan dan minuman yang terdaftar di Bursa Efek Indonesia (BEI) dari tahun 2013-2017 yang laporan keuangannya dipublikasikan secara berkala (triwulan).

Ukuran Perusahaan adalah skala besar kecilnya perusahaan yang dapat diklasifikasi berdasarkan berbagai cara, antara lain dengan ukuran pendapatan, total asset, dan total ekuitas (Agustina dan Gede; 2017). Ukuran perusahaan berhubungan dengan kualitas laba karena semakin besar perusahaan maka semakin tinggi pula kelangsungan usaha suatu perusahaan dalam meningkatkan kinerja keuangan sehigga perusahaan tidak perlu melakukan praktek manipulasi laba (Gahani dan Wayan; 2017).

Struktur modal diukur dari tingkat leveragenya (Gahani dan Wayan; 2017). Struktur modal yang diukur dengan leverage merupakan suatu variabel untuk mengetahui seberapa besar asset perusahaan dibiayai oleh hutang perusahaan. Utang yang dimiliki perusahaan berhubungan dengan keuntungan yang akan diperoleh perusahaan. Struktur modal mempunyai pengaruh terhadap kualitas laba karena jika asset perusahaan lebih besar dibiayai oleh hutang daripada modalnya maka peran daripada investor menjadi menurun. Perusahaan dinilai tidak dapat menjaga keseimbangan financial dalam penggunaan dana antara jumlah modal yang tersedia dengan modal yang dibutuhkan. Semakin tinggi hutang perusahaan, maka perusahaan tersebut akan semakin dinamis. Investasi yang meningkat menunjukkan adanya prospek keuntungan di masa yang akan datang. Oleh karena itu, jika tingkat leverage suatu perusahaan semakin tinggi maka kualitas laba akan semakin rendah (Alfiati; 2016). Pihak manajemen akan lebih terpacu untuk meningkatkan kinerjanya agar hutang-hutang perusahaan dapat terpenuhi sehingga dampak positifnya adalah perusahaan akan lebih berkembang.

Likuiditas menunjukkan perusahaan mampu untuk memenuhi kewajiban finansialnya dalam jangka pendek menggunakan dana lancar yang tersedia (Prawisanti dan Bagus; 2014). Namun apabila likuiditas perusahaan terlalu besar maka perusahaan tersebut berarti tidak mampu mengelola aktiva lancarnya semaksimal mungkin sehingga kinerja keuangan menjadi kurang baik dan kemungkinan adanya manipulasi laba untuk mempercantik informasi laba tersebut. Likuiditas menyatakan 
bahwa likuiditas memiliki hubungan yang lemah dan negatif pada kualitas laba. Menurut hasil penelitian yang dilakukan oleh Alfiati menyatakan bahwa rendahnya kualitas laba akan ratio yang tinggi biasanya dianggap menunjukkan tidak terjadi masalah dalam likuiditas, sehingga semakin tinggi likuiditas artinya laba yang dihasilkan suatu perusahaan berkualitas karena manajemen perusahaan tidak perlu melakukan praktik manajemen laba (Alfiati; 2016).

Investment Opportunity Set (IOS), merupakan keputusan investasi dalam bentuk kombinasi asset dan pilihan investasi di masa yang akan datang (Agustina dan Gede; 2017). IOS juga dapat digunakan untuk mengetahui nilai aset dan nilai perusahaan di masa depan. Dengan demikian ketika perusahaan memiliki IOS yang tinggi maka nilai perusahaan akan meningkat karena lebih banyak investor yang tertarik untuk berinvestasi dengan harapan memperoleh return yang lebih besar di masa yang akan datang. Hal tersebut yang menyebabkan adanya kemungkinan manajemen perusahaan melakukan manajemen laba karena untuk mempertahankan pertumbuhan perusahaan (Paulina dan Rusiti; 2014).

Profitabilitas
kemampuan perusahaan untuk
menghasilkan laba. Profitabilitas
perusahaan dapat dilihat dari laba
yang dihasilkan dibandingkan
dengan jumlah dana yang
diinvestasikan dalam aktiva atau
jumlah ekuitas perusahaan. Hal ini
akan menunjukkan apakah
perusahaan efektif dalam

menjalankan kegiatan operasionalnya (Anjelica dan Prasetyawan; 2014).

Laporan keuangan memiliki banyak manfaat yang digunakan oleh para penggunanya, tetapi yang mendapat perhatian lebih adalah informasi laba. Informasi laba suatu perusahaan belum menjamin bahwa laba akuntasi tersebut memiliki kualitas (Iin dan Subowo; 2015).

Dari hasil identifikasi masalah yang ditemukan. Dapat dikatakan bahwa penelitian ini dilakukan untuk menguji kembali variabel-variabel yang berpengaruh terhadap kualitas laba berdasarkan temuan dari peneliti sebelumnya. Dan juga agar penulis dapat mengetahui apakah hasil penelitian ini sejalan dengan penelitian terdahulu atau tidak.

\section{KAJIAN PUSTAKA DAN PENGEMBANGAN HIPOTESIS}

\section{Kajian Teoritis}

Teori agensi adalah hubungan antara prinsipal dengan agen , yang dimaksud prinsipal adalah pihak yang memberikan tugas yang wajib diselesaikan dalam kurun waktu tertentu sesuai dengan kondisi kebutuhan dari prinsipal, dan yang dimaksud agen adalah pihak yang menerima tugas atau pekerjaan untuk diselesaikan dalam kurun waktu tertentu sesuai dengan yang diperintahkan oleh prinsipal, hubungan ini dapat lebih dari satu prinsipal untuk memberikan tugas kepada agen yang akan mengerjakan tugas yang diberikan (Jones; 1991).

Informasi merupakan unsur penting bagi investor dan pelaku bisnis karena informasi pada 
hakekatnya menyajikan keterangan, catatan atau gambaran baik untuk keadaan masa lalu, saat ini maupun keadaan masa yang akan datang bagi kelangsungan hidup suatu perusahaan. Informasi yang lengkap, relevan, akurat dan tepat waktu sangat diperlukan oleh investor di pasar modal untuk analisis mengambil keputusan investasi.

Di dalam perusahaan memiliki dua bagian penting yaitu orang yang berperan sebagai prinsipal dan manajemen orang yang berperan sebagai agent. Prinsipal cenderung menginginkan perusahaannya dapat terus berjalan (going concern) dan mendapatkan return yang sebesar-besarnya atas investasi yang dilakukan, sedangkan manajemen menginginkan kompensasi yang tinggi atas kinerjanya. Pihak manajemen selaku pengelola perusahaan memiliki informasi tentang perusahaan yang lebih banyak daripada para pemegang saham sehingga terjadi asimetri informasi. Hal ini dapat menyebabkan manajemen melakukan praktek akuntansi yang berorientasi pada laba untuk mencapai kinerja tertentu (Dira dan Astika; 2014).

Konflik keganenan menyebabkan terjadinya sifat manajemen yang melaporkan laba secara oportunis untuk memaksimalkan kepentingan pribadinya. Jika hal ini terjadi maka berakibat pada rendahnya kualitas laba yang dihasilkan. Rendahnya kualitas laba dapat mengakibatkan para penggunanya membuat kesalahan dalam pengambilan keputusan (Wati dan Putra; 2017).
Laba yang tidak menunjukkan informasi kinerja manajemen yang sebenarnya akan membuat pihak pengguna laporan menjadi tersesat (Dira dan Astika; 2014). Laba dapat dikatakan berkualitas tinggi jika laba yang dilaporkan tersebut dapat digunakan oleh pengguna laporan keuangan untuk membuat keputusan yang terbaik dan memenuhi karakteristik kualitatif laporan keuangan yaitu relevan dan reliabilitas (Silfi; 2016).

Jadi dapat disimpulkan bahwa teori agensi merupakan suatu kontrak satu orang atau lebih (prinsipal) memerintah orang lain (agen) untuk melakukan suatu jasa atas nama prinsipal serta memberi wewenang kepada agen untuk membuat keputusan yang terkait bagi prinsipal.

Berdasarkan teori agensi,
pada penelitian ini penulis
menggunakan faktor-faktor yang
diasumsikan dapat mempengaruhi
kualitas laba yaitu ukuran
perusahaan, struktur modal,
likuiditas, investment opportunity
set, dan profitabilitas.

\section{Pengembangan Hipotesis}

\section{- Pengaruh Ukuran Perusahaan} Terhadap Kualitas Laba

Ukuran perusahaan adalah skala besar kecilnya perusahaan yang dapat diklasifikasikan berdasarkan berbagai cara antara lain dengan ukuran pendapatan, total aset, dan total ekuitas (Brigham dan Houston; 2001). Ukuran perusahaan dinyatakan dengan total aset, jika semakin besar total aset perusahaan maka akan semakin besar pula ukuran perusahaan tersebut. Perusahaan yang memiliki total aset besar menunjukkan bahwa perusahaan tersebut relatif stabil dan mampu 
menghasilkan laba yang lebih besar dibandingkan dengan perusahaan yang memiliki total aset sedikit atau rendah.

Menurut hasil penelitian yang dilakukan oleh Dira \& Astika (2014) menyatakan bahwa ukuran perusahaan berpengaruh positif terhadap kualitas laba. Hasil penelitian tersebut juga sejalan dengan Jaya \& Wirama (2017) yang menyatakan bahwa ukuran perusahaan berpengaruh positif terhadap kualitas laba. Begitu pula, dengan hasil penelitian Anjelica \& Prasetyawan (2014) yang menyatakan bahwa ukuran perusahaan berpengaruh positif terhadap kualitas laba.

Namun, hasil penelitian diatas tidak sejalan dengan Warianto \& Rusiti (2014) yang menyatakan bahwa ukuran perusahaan berpengaruh negatif terhadap kualitas laba.

Berdasarkan hasil penelitian diatas serta teori yang dikemukakan. Maka hipotesis yang diajukan adalah sebagai berikut:

$\mathrm{H}_{1}$ : Ukuran perusahaan berpengaruh terhadap kualitas laba

\section{- Pengaruh Struktur Modal Terhadap Kualitas Laba}

Struktur modal diukur dengan leverage karena untuk mengetahui seberapa besar aset perusahaan yang dibiayai oleh hutang perusahaan. Perusahaan yang memiliki hutang yang tinggi bisa berdampak pada risiko keuangan yang semakin besar yaitu kemungkinan perusahaan tidak mampu membayar utang-utangnya. Adanya risiko gagal bayar dapat menyebabkan biaya yang harus dikeluarkan perusahaan untuk mengatasi hal tersebut semakin besar sehingga akan menurunkan laba perusahaan.
Hasil penelitian yang dilakukan oleh Warianto \& Rusiti (2014) menyatakan bahwa struktur modal berpengaruh positif terhadap kualitas laba. Begitu pula dengan hasil penelitian yang dilakukan oleh Silfi (2016) yang menyatakan bahwa struktur modal berpengaruh terhadap kualitas laba. Dan hasil penelitian diatas juga diperkuat oleh Risdawaty \& Subowo (2015) yang menyatakan bahwa struktur modal berpengaruh positif cterhadap kualitas laba.

Namun, hasil penelitian diatas tidak sejalan dengan Sadiah dan Priyadi (2015) yang menyatakan bahwa struktur modal berpengaruh negatif terhadap kualitas laba.

Berdasarkan hasil penelitian diatas serta teori yang dikemukakan, maka hipotesis yang diajukan adalah sebagai berikut:

$\mathrm{H}_{2}$ : Struktur modal berpengaruh terhadap kualitas laba

\section{- Pengaruh Likuiditas Terhadap} Kualitas Laba

Likuiditas menunjukkan bahwa perusahaan mampu untuk memenuhi kewajiban finansialnya dalam jangka pendek menggunakan dana lancar yang tersedia. Namun apabila likuiditas perusahaan terlalu besar maka perusahaan tersebut berarti tidak mampu mengelola aktiva lancarnya semaksimal mungkin sehingga kinerja keuangan menjadi kurang baik dan kemungkinan ada manipulasi laba untuk mempercantik informasi laba tersebut.

Berdasarkan hasil penelitian yang dilakukan oleh Warianto \& Rusiti (2014) yang menyatakan bahwa likuiditas berpengaruh negatif terhadap 
kualitas laba. Hasil penelitian tersebut sejalan dengan Irawati (2012) yang menyatakan bahwa likuiditas berpengaruh negatif terhadap kualitas laba. Namun, hasil penelitian diatas tidak sejalan dengan Wulandari (2013) yang menyatakan bahwa likuiditas berpengaruh positif terhadap kualitas laba.

Berdasarkan hasil penelitian diatas serta teori yang dikemukakan, maka hipotesis yang diajukan adalah sebagai berikut:

$\mathrm{H}_{3}$ : Likuiditas berpengaruh terhadap kualitas laba

\section{- Pengaruh Investment Opportunity} Set (IOS) Terhadap Kualitas Laba

Investment opportunity set adalah nilai kesempatan investasi yang merupakan nilai sekarang dari pilihanpilihan perusahaan untuk membuat investasi dimasa mendatang. Pilihanpilihan yang akan dilakukan perusahaan di masa mendatang akan mempengaruhi nilai dari perusahaan itu sendiri.

Jika manajer telah melakukan tindakan tidak sesuai keinginan principal maka telah terjadi perbedaan kepentingan antara agen dan prinsipan (Konflik Keagenan). Dengan adanya perbedaan kepentingan tersebut manajer dapat melakukan hal-hal yang meningkatkan keuntungan bagi dirinya sendiri yang kemungkinan akan merugikan pemilik perusahaan misalnya melakukan manajemen laba, dengan adanya manajemen laba dalam perusahaan akan mengakibatkan rendahnya kualitas laba perusahaan sehingga para pemakai laporan keuangan akan melakukan kesalahan dalam mengambil keputusan.
Hasil penelitian yang dilakukan oleh Warianto \& Rusiti (2014) yang menyatakan bahwa investment opportunity set berpengaruh positif terhadap kualitas laba. Namun, hasil penelitian tersebut tidak sejalan dengan Jaya \& Wirama (2017) yang menyatakan bahwa investment opportunity set berpengaruh negatif terhadap kualitas laba.

Berdasarkan hasil penelitian diatas serta teori yang dikemukakan, maka hipotesis yang diajukan adalah sebagai berikut:

$\mathrm{H}_{4}$ : Investment Opportunity Set (IOS) berpengaruh terhadap kualitas laba

\section{- Pengaruh Profitabilitas Terhadap} Kualitas Laba

Return on Asset (ROA) adalah rasio keuangan perusahaan yang berhubungan dengan aspek earnings atau profitabilitas. Return on Asset (ROA) berfungsi untuk mengukur efektifitas perusahaan dalam menghasilkan laba dan memanfaatkan aktiva yang dimilikinya. Semakin besar return on asset (ROA) suatu perusahaan, semakin besar pula tingkat keuntungan yang dicapai oleh perusahaan tersebut. Maka bisa dikatakan juga perusahaan tersebut memiliki kualitas laba yang baik.

Menurut hasil penelitian yang dilakukan oleh Setiawan (2017) menyatakan bahwa profitabilitas berpengaruh positif terhadap Kualitas laba. Namun, hasil penelitian diatas tidak sejalan dengan Risdawaty dan Subowo (2015) yang menyatakan bahwa Profitabilitas berpengaruh negatif terhadap kualitas laba.

Berdasarkan hasil penelitian diatas serta teori yang dikemukakan, Maka hipotesis yang akan diajukan adalah sebagai berikut: 
$\mathrm{H}_{5}$ : Profitabilittas berpengaruh

terhadap kualitas laba

\section{METODE PENELITIAN \\ Populasi dan Sampel}

Metode penelitian sampel yang digunakan adalah Purposive Sampling, yaitu tipe pemilihan sampel berdasarkan pertimbanganpertimbangan tertentu dan pertimbangan yang diambil itu berdasarkan tujuan penelitian. Sampel untuk penelitian ini adalah Perusahaan sub sektor makanan dan minuman yang terdaftar di Bursa Efek Indonesia (BEI) selama tahun 2013-2017. Dari hasil pemilihan sampel dengan menggunakan Purposive Sampling terpilih 7 perusahaan yang memenuhi kriteria.

\section{Definisi Operasional Variabel Kualitas Laba (Y)}

Variabel dependen dalam penelitian ini adalah kualitas laba. Kualitas laba sebagai sejauh mana perusahaan mengaplikasikan konservatisme perusahaan dengan kualitas laba tinggi diharapkan memiliki rasio tinggi terhadap laba yang lebih tinggi dibandingkan perusahaan dengan kualitas rendah (Pilianti; 2014). Pada penelitian ini kualitas laba diukur dengan menggunakan perhitungan Quality Of Income.

Rasio Quality of Income menunjukkan varians antara arus kas dengan laba bersih. Semakin tinggi rasio maka semakin tinggi kualitas laba karena makin besar laba operasi yang direalisasikan dalam bentuk kas (Widjaja dan Maghviroh; 2011).

Perhitungan Quality of Income dapat dijabarkan sebagai berikut:

$$
\text { Quality of Income }=\frac{\text { Arus Kas Operasi }}{E B I T}
$$

\section{Ukuran Perusahaan (X1)}

Ukuran perusahaan adalah skala besar kecilnya perusahaan yang dapat diklasifikasi berdasarkan berbagai cara, antara lain dengan ukuran pendapatan, total aset, dan total ekuitas (Agustina dan Gede; 2017).

Ukuran perusahaan diukur dengan logaritma natural (Ln) dari total aset. Hal ini dikarenakan besarnya total aset masing-masing perusahaan berbeda bahkan mempunyai selisih yang besar, sehingga dapat menyebabkan nilai yang ekstrim. Unruk menghindari adanya data yang ridak normal tersebut maka data total aset perlu di Ln kan (Diah Aristya Hesti; 2010).

$$
\begin{aligned}
& \quad \text { Pada penelitian ini, ukuran } \\
& \begin{array}{l}
\text { perusahaan dihitung } \\
\text { menggunakan rumus: }
\end{array}
\end{aligned}
$$

Ukuran Perusahaan $=$ Ln Total Aset

\section{Struktur Modal $\left(\mathbf{X}_{2}\right)$}

Struktur modal diukur dengan leverage karena untuk mengetahui seberapa besar aset perusahaan yang dibiayai oleh hutang perusahaan. Perusahaan yang memiliki hutang yang tinggi bisa berdampak pada risiko keuangan yang semakin besar yaitu kemungkinan perusahaan tidak mampu membayar utang-utangnya (Silfi; 2016).

Adanya risiko gagal bayar dapat menyebabkan biaya yang harus dikeluarkan perusahaan untuk mengatasi hal tersebut semakin besar sehingga akan menurunkan laba perusahaan (Warianto dan Rusiti; 2014).

Pada penelitian ini, struktur modal dihitung dengan menggunakan rumus: 


$$
\text { Leverage }=\frac{\text { Utang }}{\text { Modal }}
$$

Likuiditas $\left(\mathbf{X}_{3}\right)$

Menurut Fahlevi (2016), likuiditas adalah kemampuan perusahaan untuk membayar kewajibankewajibannya yang segera harus dipenuhi. Kewajiban yang harus dipenuhi hutang jangka pendek, oleh karena itu rasio ini bisa digunakan untuk mengukur tingkat keamanan kredit jangka pendek, serta mengukur apakah operasi perusahaan tidak akan terganggu bila kewajiban jangka pendek ini segera ditagih.

Rasio likuiditas yang umum digunakan adalah current ratio. Current ratio yang tinggi biasanya dianggap menunjukkan tidak terjadi masalah dalam likuiditas, sehingga semakin tinggi likuiditas artinya laba yang dihasilkan suatu perusahaan berkualitas karena manajemen perusahaan tidak perlu melakukan praktik manajemen laba (Warianto dan Rusiti; 2014).

Rumus yang digunakan untuk mencari likuiditas dapat digunakan dengan cara sebagai berikut:

$$
\text { Current Ratio }=\frac{\text { Aktiva Lancar }}{\text { Hutang Lancar }}
$$

\section{Investment Opportunity Set (X4)}

Investment opportunity set merupakan kesempatan perusahaan untuk tumbuh. Investment opportunity set dijadikan sebagai dasar untuk menentukan klasifikasi pertumbuhan perusahaan di masa depan. Nilai investment opportunity set bergantung pada pengeluaran-pengeluaran yang ditetapkan manajemen di masa yang akan datang (future discretionary expenditure) karena pada saat ini merupakan pilihan- pilihan investasi dan diharapkan akan menghasilkan return lebih besar dari biaya ekuitas (cost of equity) dan dapat menghasilkan keuntungan (Warianto dan Rusiti; 2014).

Pada penelitian ini, investment opportunity set dihitung dengan menggunakan rumus market value to book value of assets:

MVVVA =T. Aset-T. Ekuitas + (Jml Saham Beredar X Harga Penutupan Saham) Total Aset

\section{Profitabilitas $\left(\mathbf{X}_{\mathbf{5}}\right)$}

Profitabilitas adalah kemampuan perusahaan memperoleh laba dalam hubungannya dengan penjualan, total aktiva maupun modal sendiri (Agus Sartono, 2010). Salah satu rasio profitabilitas adalah ukuran return on asset (ROA) yang merupakan perbandingan laba bersih dengan total aset. Return on Asset (ROA) menunjukkan efektifitas perusahaan dalam mengelola aset baik dari modal sendiri maupun dari modal pinjaman, investor akan melihat seberapa efektif suatu perusahaan dalam mengelola aset. Secara matematis dirumuskan sebagai berikut:

$$
\text { Return On Asset }=\frac{\text { Laba Setelah Pajak }}{\text { Total Asset }}
$$

\section{Pegujian Hipotesis}

Analisis Statistik Deskriptif

Analisis statistik deskriptif adalah statistik yang digunakan untuk menganalisis data dengan cara mendeskripsikan atau menggambarkan 
data yang telah terkumpul sebagaimana datanya tanpa bermaksud membuat kesimpulan yang berlaku untuk umum atau generalisasi (Sugiyono; 2014). Analisis statistik deskriptif memberikan deskripsi atau gambaran suatu data yang dilihat dari rata-rata (mean), standar deviasi, varian, maksimum, minimum (Warianto dan Rusiti; 2014).

\section{Estimasi Regresi Data Panel}

Dalam mengestimasi model regresi dengan menggunakan data panel terdapat tiga pendekatan yang dapat digunakan yaitu ordinary leastsquare (OLS) atau commont effect model, metode efek tetap (fixed effect model) dan metode efek random (random effect model) (Basuki dan Prawoto; 2016).

\section{Common Effect Model atau Ordinary Least Square}

Common Effect Model merupakan pendekatan data panel yang paling sederhana. Model ini tidak memerhatikan dimensi individu maupun waktu sehingga diasumsikan bahwa perilaku antar individu sama dalam berbagai kurun waktu. Model ini mengkombinasikan antara data time series dan cross section dalam bentuk pool, mengestimasinya menggunakan pendekatan kuadrat terkecil (pooled least square).

Adapun persamaan regresi dalam common effect model dapat ditulis sebagai berikut:

$$
Y_{i t}=\alpha+X_{i t} \beta+\varepsilon_{i t}
$$

Di mana:

$\mathrm{i}=$ menunjukan cross section (individu)

$\mathrm{t}=$ menunjukan periode waktu Dengan asumsi komponen error dalam pengolahan kuadrat terkecil biasa, proses estimasi secara terpisah untuk setiap unit cross section dapat dilakukan (Basuki dan Prawoto; 2016).

\section{Model Fixed Effect}

Model fixed effects mengasumsikan bahwa terdapat efek yang berbeda antar individu. Perbedaan itu dapat diakomodasi melalui perbedaan pada intersepnya, dimana perbedaan intersep itu bisa terjadi karena perbedaan budaya kerja, manajerial dan insentif. Namun demikian, slopnya sama antar perusahaan. Oleh karena itu, dalam model fixed effects, setiap merupakan parameter yang tidak diketahui dan akan diestimasi dengan menggunakan teknik variabel dummy yang dapat ditulis sebagai berikut:

$\left[\begin{array}{l}y 1 \\ y 2 \\ y n\end{array}\right]=\left[\begin{array}{l}\alpha \\ \alpha \\ \alpha\end{array}\right]+\left[\begin{array}{lll}i & 0 & 0 \\ 0 & i & 0 \\ 0 & 0 & i\end{array}\right]\left[\begin{array}{l}\alpha 1 \\ \alpha 2 \\ \alpha n\end{array}\right]+\left[\begin{array}{lll}x 11 & x 21 & x p 1 \\ x 12 & x 22 & x p 2 \\ x 1 n & x 2 n & x p n\end{array}\right]\left[\begin{array}{l}\beta 1 \\ \beta 2 \\ \beta n\end{array}\right]+\left[\begin{array}{l}\varepsilon 1 \\ \varepsilon 1 \\ \varepsilon n\end{array}\right]$

Teknik seperti di atas dinamakan Least Square Dummy Variabel (LSDV). Selain diterapkan untuk efek setiap individu, LSDV ini juga dapat mengakomodasi efek waktu yang bersifat sistemik. Hal ini dapat dilakukan melalui penambahan variabel dummy waktu di dalam model (Basuki dan Prawoto; 2016).

\section{Random Effect Model}

Berbeda dengan fixed effects model, efek spesifik dari masing-masing individu diperlakukan sebagai bagian dari komponn eror yang bersifat acak dan tidak berkorelasi dengan variabel penjelas yang teramati, model seperti ini dinamakan Random Effects Model (REM). Model ini sering disebut juga dengan Error Component Model (ECM). Dengan demikian, persamaan model random effects dapat dituliskan sebagai berikut:

$$
\mathrm{Y}_{\mathrm{it}}=\alpha+\mathrm{X}^{{ }_{\mathrm{it}} \beta} \beta+\mathrm{w}_{\mathrm{it}}
$$


Di mana:

$$
\begin{aligned}
& \mathrm{W}_{\mathrm{it}}=\varepsilon_{\mathrm{it}}+\mathrm{u}_{1} ; \mathrm{E}\left(\mathrm{w}_{\mathrm{it}}\right)=0 ; \mathrm{E}\left(\mathrm{w}_{\mathrm{it}}{ }^{2}\right)=\alpha^{2}+ \\
& \quad \alpha_{\mathrm{u}}^{2} ; \\
& \mathrm{E}\left(\mathrm{w}_{\mathrm{it}}, \mathrm{w}_{\mathrm{jt}-1}\right)=0 ; \mathrm{i}+\mathrm{j} ; \mathrm{E}\left(\mathrm{u}_{\mathrm{i}}, \varepsilon_{\mathrm{it}}\right)=0 ; \\
& \mathrm{E}\left(\varepsilon_{\mathrm{it}}, \varepsilon_{\mathrm{jt}}\right)=\mathrm{E}\left(\varepsilon_{\mathrm{it}}, \varepsilon_{\mathrm{js}}\right)=0
\end{aligned}
$$

Meskipun komponen error $\mathrm{w}_{\mathrm{t}}$ bersifat homoskedastik, nyatanya terdapat korelasi antara $\mathrm{w}_{\mathrm{t}}$ dan wit-s (equicorrelation), yakni:

$\operatorname{Corr}\left(\mathrm{w}_{\mathrm{it},}, \mathrm{W}_{\mathrm{i}(\mathrm{t}-1)}\right)=\alpha_{\mathrm{u}}^{2} /\left(\alpha^{2}+\alpha_{\mathrm{u}}^{2}\right)$

Karena itu, metode OLS tidak bisa digunakan untuk mendapatkan estimator yang efisien bagi model random effects. Metode yang tepat untuk mengestimasi model random effects adalah Generalized Least Square (GLS) dengan asumsi homoskedastik dan tidak ada cross-sectional correlation (Basuki dan Prawoto; 2016).

\section{Teknik Pemilihan Model Regresi Data Panel}

Untuk menentukan model regresi data panel yang tepat untuk digunakan dalam analisis regresi data panel maka kita dapat melakukan pengujian sebagai berikut:

\section{Uji Chow}

Uji chow digunakan untuk memilih model yang digunakan apakah sebaiknya menggunakan Common Effect Model (CEM) atau Fixed Effect Model (FEM). Pengujian ini dapat dilihat pada nilai Probabilitas (Prob) (Eksandy dan Heriyanto;2017). Crosssection $\mathrm{F}$ dan Cross-section chi-square dengan hipotesis sebagai berikut:

H0: Model mengikuti Common Effect Model (CEM) jika Probabilitas Ceoss-section $\mathrm{F}$ dan Cros-section chi-square $>\alpha(0,05)$

Ha: Model mengikuti Fixed Effect Model (FEM) jika Probabilitas
Cross-section $\mathrm{F}$ dan Cross-section chi-square $<\alpha(0,05)$.

\section{Uji Hausman}

Uji Hausman digunakan untuk memilih model yang digunakan apakah sebaiknya menggunakan Random Effect Model (REM) atau Fixed Effect Model (FEM). Pengujian ini dapat dilihat pada nilai Probabilitas (Prob) (Eksandy dan Heriyanto; 2017). Cross-section random dengan hipotesis sebagai berikut:

H0: Model mengikuti Random Effect Model (REM) jika nilai Probabilitas (Prob). Cross-section random $>\alpha(0,05)$.

Ha: Model mengikuti Fixed Effect Random (FEM) jika nilai Probabilitas (Prob). Cross-section random $<\alpha(0,05)$.

\section{Uji Lagrange Multiplier}

Uji Langrange Multiplier digunakan untuk memilih model yang digunakan apakah sebaiknya menggunakan Random Effect Model (REM) atau Common Effect Model (CEM) (Eksandy dan Hariyanto; 2017).

Pengujian ini dapat dilihat pada nilai Probabilitas Breush-pagan dengan hipotesis sebagai berikut:

H0: Model mengikuti Common Effect Model (CEM) jika nilai Probabilitas Cross-section Breush-pagan $>\alpha(0,05)$.

Ha: Model mengikuti Random Effect Model (REM) jika nilai Probabilitas Cross-section Breush-pagan < $\alpha(0,05)$.

\section{Uji Asumsi Klasik}

Uji asumsi klasik adalah persyaratan statistic yang harus dipenuhi pada analisis regresi yang menggunakan pendekatan Ordinary Least Squared (OLS) dalam teknik estimasinya. Dalam 
regresi data panel model yang berbasis Ordinary Least Squared (OLS) adalah Common Effect Model (CEM) dan Fixed Effect Model (FEM), dengan demikian perlu dilakukan uji asumsi klasik apabila model regresi yang digunakan dalam bentuk Common Effect Nidek (CEM) atau Fixed Effect Model (FEM).

Uji asumsi klasik terdiri dari uji Linieritas, Autokorelasi, Multikolineritas dan Normalitas. Walaupun demikian, tidak semua uji dilakukan dalam regresi data panel, hanya Uji Multikolinieritas dan Heterosdastisitas saja yang diperlukan.

\section{Uji Multikolineritas}

Uji multikolineritas perlu dilakukan pada regresi yang menggunakan lebih dari satu variabel bebas, hal ini untuk mengetahui apakah terjadi hubungan saling mempengaruhi antara variabel bebas yang diteliti.

\section{Uji Heteroskedastisitas}

Uji heteroskedastisitas perlu dilakukan untuk mengetahui ada atau tidaknya ketidaksamaan varian dari residual model regresi data panel. Pengujian ini dapat dilihat pada nilai Probabilitas Breush-Pagan LM dengan hipotesis sebagai berikut:

H0: Jika nilai Prob. Breusch-Pagan LM

$$
>\alpha 0,05
$$

Ha: Jika nilai Prob. Breusch-Pagan LM

$$
<\alpha 0,05
$$

\section{Uji Hipotesis}

\section{Uji F}

Hasil Uji F menjelaskan apakah semua variabel bebas yang dimasukkan ke dalam model secara bersama-sama mempunyai perngaruh terhadap variabel terikat, atau dengan kata lain model fit atau tidak. Apabila Uji F tidak berpengaruh maka penelitian tidak layak untuk dilanjutkan (Eksandy dan Hariyanto; 2017).

Hipotesis dalam Uji $F$ adalah sebagai berikut:

- Berdasarkan perbandingan F-statistik dengan $\mathrm{F}$ Tabel

H0: Jika nilai F-Statistik $<\mathrm{F}$ Tabel

Ha: Jika nilai F-Statistik > F Tabel

Jika F-statistik $<\mathrm{F}_{\text {Tabel, }}$

maka H0 diterima yang artinya variabel independen (X) secara bersama-sama tidak berpengaruh terhadap variabel dependen (Y). Namun sebaliknya, jika F-statistik > F Tabel maka Ha diterima artinya variabel independen (X) secara bersama-sama berpengaruh terhadap variabel dependen (Y).

- Berdasarkan probabilitas

H0: Jika nilai Prob (F-statistik) $>\alpha$ 0,05

Ha: Jika nilai Prob (F-statistik) $<\alpha$ 0,05

Jika Prob (F-statistik) $>\alpha 0,05$, maka H0 diterima yang artinya variabel independen (X) secara bersama-sama tidak berpengaruh terhadap variabel dependen (Y). Namun sebaliknya, jika Prob (FStatistik) $<\alpha 0,05$, maka Ha diterima artinya variabel independen (X) secara bersama-sama berpengaruh terhadap variabel dependen $(\mathrm{Y})$.

\section{Uji $R^{2}$ (Koefisien Determinasi)}

Hasil koefisien determinasi menjelaskan seberapa jauh kemampuan model regresi dalam menerangkan variasi variabel bebas mempengaruhi variabel terikat. Nilai $\mathrm{R}$-squared akan menunjukkan seberapa besar $\mathrm{X}$ akan memperngaruhi pergerakan Y. Semakin besar hasl R- 
squared akan semakin baik karena hal ini mengidentifikasi semakin baik variabel independen dalam menjelaskan variabel dependen (Eksandy dan Heriyanto; 2015).

Nilai R-squared berada antara 0 sampai 1 dengan penjelasan sebagai berikut:

- Nilai R-squarded harus berkisar 0 sampai 1

- Jika nilai R-squared sama dengan 1, berarti naik atau turunnya variabel terikat (Y) 100\% dipengaruhi oleh variabel bebas (X)

- Jika nilai R-squared sama dengan 0 , berarti tidak ada hubungan sama sekali antara variabel independen terhadap variabel.

Uji t

Hasil uji $t$ menjelaskan signifikansi pengaruh variabel bebas secara parsial terhadap variable terikat. Hipotesis dalam uji t adalah sebagai berikut:

1) Berdasarkan perbandingan tstatistik dengan $t$ tabel

H0: Jika nilai t-statistik $<\mathrm{t}$ tabel

Ha: Jika nilai t-statistik $>\mathrm{t}$ tabel

Jika nilai t-statistik < t tabel, maka H0 diterima yang artinya variabel independen (X) secara parsial tidak berpengaruh terhadap variabel dependen (Y). Namun sebaliknya, jika nilai t-statistik > $\mathrm{t}$ tabel, maka Ha diterima artinya variabel independen (X) secara parsial berpengaruh terhadap variabel dependen (Y).

2) Berdasarkan Probabilitas

H0: Jika nilai Prob $>\alpha 0,05$

Ha: Jika nilai Prob $<\alpha$ 0,05Jika nilai

Prob $>\alpha 0,05$,

maka H0 diterima yang artinya variabel independen $(\mathrm{X})$ secara parsial tidak berpengaruh terhadap variabel dependen (Y). Namun sebaliknya, jika nilai Prob $<\alpha 0,05$, maka Ha diterima yang artinya variabel independen $(\mathrm{X})$ secara parsial berpengaruh terhadap variabel dependen (Y).

\section{Analisis Regresi Data Panel}

Analisis data panel adalah gabungan antara data cross section dan data time series, dimana unit cross section yang sama diukur pada waktu yang berbeda. Maka dengan kata lain, data panel merupakan data dari beberapa individu (sampel) yang diamati dalam beberapa kurun waktu tertentu (Eksandy dan Heriyanto; 2015).

$$
Y_{i}=\alpha+\beta_{1} X 1_{i}+\beta_{2} X 2_{i}+\beta_{3} X 3_{i}+\beta_{4} X 4_{i}+e_{i}
$$




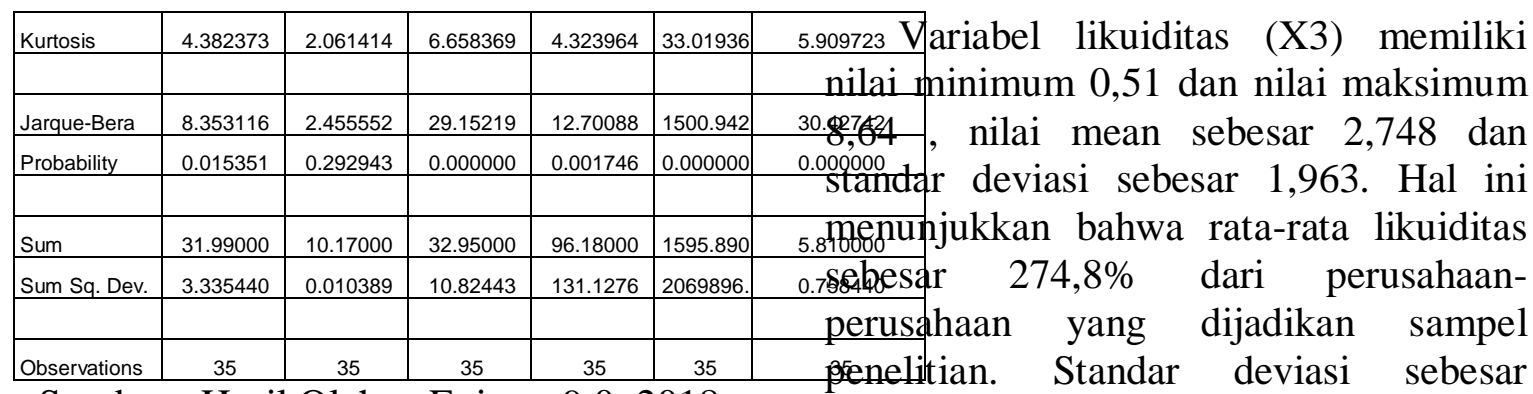

Sumber : Hasil Olahan Eviews 9.0, 2018 196,38\% menunjukkan likuiditas pada

Berdasarkan tabel diatas dapat dideskripsikan bahwa kualitas laba sebagai variabel dependen (y) memiliki nilai terendah 0,05 dan nilai tertinggi 1,44 nilai rata-rata (mean) sebesar 0,914 dengan standar deviasi sebesar 0,313 . Nilai mean sebesar $0,914 \quad(91,4 \%)$ menunjukkan bahwa rata-rata kualitas laba perusahaan-perusahaan sampel yang diteliti adalah sebesar $91,4 \%$ dari total kualitas laba. Standar deviasi sebesar $31,32 \%$ menunjukkan bahwa kualitas laba dari perusahaan-perusahaan sampel yang diteliti memiliki perbedaan yang relative besar.

Variabel independen ukuran perusahaan (X1) memiliki nilai minimum 0,26 dan nilai maksimum 0,32 , nilai mean sebesar 0,290 dan standar deviasi sebesar 0,017, hal ini menunjukkan bahwa $29,06 \%$ rata rata ukuran perusahaan digunakan untuk membiayai modal. Standar deviasi sebesar $1,748 \%$ menunjukkan total ukuran perusahaan dari perusahaan-perusahaan sampel yang diteliti memiliki perbedaan yang relatif besar.

Variabel struktur modal (X2) memiliki nilai minimum 0,01 dan nilai maksimum 3,03, nilai mean sebesar 0,941 dan standar deviasi sebesar 0,564. Hal ini menunjukkan bahwa 94,14\% rata rata struktur modal perusahaan diisi oleh utang terhadap modal. Standar deviasi sebesar 56,42\% menunjukkan struktur modal dari perusahaan-perusahaan sampel yang diteliti memiliki perbedaan yang relatif besar. perusahaan-perusahaan sampel yang diteliti memiliki perbedaan relatif besar.

Variabel investment opportunity set (X4) memiliki nilai minimum 0,85 dan nilai maksimum 1463,500, nilai mean sebesar 45,596 dan standar deviasi sebesar 246,737. Hal ini menunjukkan bahwa rata-rata investment opportunity set sebesar 4.559,69\% dari perusahaanperusahaan yang dijadikan sampel penelitian. Standar deviasi sebesar $24.673,73 \%$ menunjukkan investment opportunity set pada perusahaanperusahaan sampel yang diteliti memiliki perbedaan yang relatif besar.

Variabel profitabilitas (X5) memiliki nilai minimum 0,02 dan nilai maksimum 0,680 nilai mean sebesar 0,166 dan standar deviasi sebesar 0,149. Hal ini menunjukkan bahwa rata-rata profitabilitas sebesar $16,6 \%$ dari perusahaan-perusahaan yang dijadikan sampel penelitian. Standar deviasi sebesar $14,935 \%$ menunjukkan profitabilitas pada perusahaan-perusahaan sampel yang diteliti memiliki perbedaan yang relatif kecil.

Nilai minimum paling kecil dari keseluruhan variabel sebesar 0,01 terletak pada struktur modal, sedangkan nilai maksimum paling besar dari seluruh variabel sebesar 8,64 yang terletak pada variabel likuiditas, nilai rata-rata paling besar 45,596 terletak pada variabel investment opportunity set, sedangkan nilai rata-rata yang paling rendah sebesar 0,166 yang terletak pada variabel profitabilitas, standar deviasi paling besar 246,737 terletak pada variabel investment opportunity set, sedangkan standar 
deviasi yang paling kecil sebesar 0,017 terletak pada variabel ukuran perusahaan.

\section{Estimasi Regresi Data Panel Common Effect Model}

Common Effect Model merupakan pendekatan model panel yang paling sederhana karena hanya mengkombinasikan data time series dan cross section. Pada model ini tidak diperhatikan dimensi waktu maupun individu, sehingga diasumsikan bahwa perilaku data perusahaan sama dalam berbagai kurun waktu. Metode ini bisa menggunakan pendekatan Ordinary Least Square (OLS) atau tekhnik kuadrat terkecil untuk mengestimasi model data panel (Basuki dan Prawoto; 2016).

Bentuk estimasi Common Effect Model adalah sebagai berikut:

\section{Common Effect Model}

Dependent Variable: KL Method: Panel Least Squares

Date: 10/08/18 Time: 02:47

Sample: 20132017

Periods included: 5

Cross-sections included: 7

Total panel (balanced) observations: 35 individu dapat diakomodasi dari perbedaan intersepnya. Untuk mengestimasi data panel model fixed effects menggunakan teknik variabel dummy untuk menangkap perbedaan intersep antar perusahaan. Model estimasi ini sering juga disebut dengan teknik Least Squares Dummy Variabel (LSDV) (Basuki dan Prawoto; 2016).

Bentuk estimasi Fixed Effect Model adalah sebagai berikut:

\section{Fixed Effect Model}

Dependent Variable: KL

Method: Panel Least Squares

Date: 10/08/18 Time: 02:57

Sample: 20132017

Periods included: 5

Cross-sections included: 7

Total panel (balanced) observations: 35

\begin{tabular}{ccccc}
\hline \hline Variable & Coefficient & Std. Error & t-Statistic & Prob. \\
\hline \hline C & 10.48029 & 4.080542 & 2.568357 & 0.0172 \\
UP & -33.33130 & 13.98718 & -2.382989 & 0.0258 \\
SM & -0.104789 & 0.174098 & -0.601898 & 0.5531 \\
LIKUIDITAS & 0.133483 & 0.047298 & 2.822182 & 0.0097 \\
IOS & -0.000111 & 0.000274 & -0.403025 & 0.6907 \\
PROFITABILITAS & -0.869179 & 0.781611 & -1.112034 & 0.2776 \\
\hline \hline & & & \\
\hline
\end{tabular}

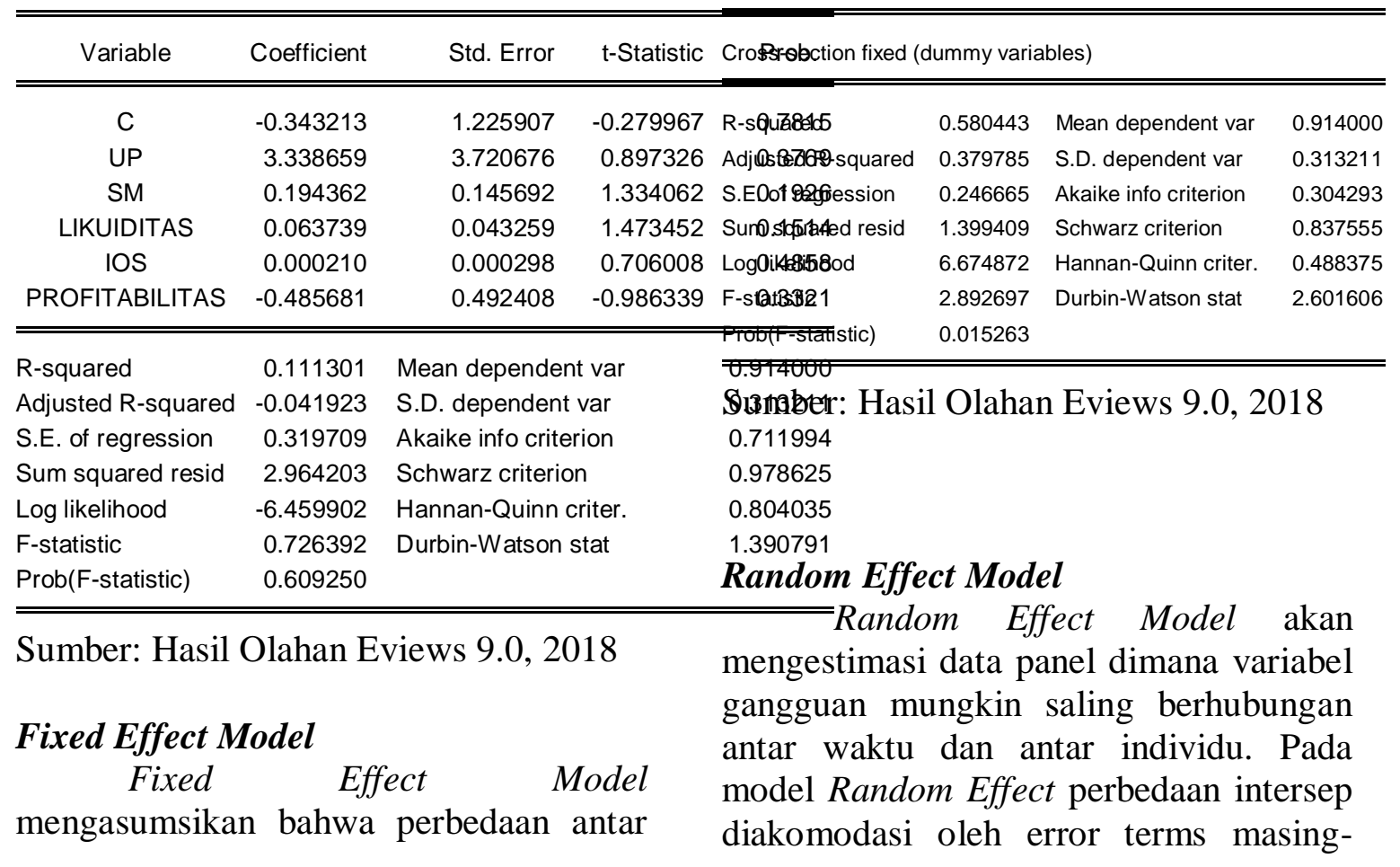


masing perusahaan. Keuntungan menggunakan model Random Effect yakni menghilangkan heteroskedastisitas. Model ini juga disebut teknik Generalized Least Square (GLS) (Basuki dan Prawoto; 2016).

Bentuk estimasi Random Effect Model adalah sebagai berikut:

\section{Random Effect Model}

Dependent Variable: KL

Method: Panel EGLS (Cross-section random effects)

Date: 10/08/18 Time: 02:58

Sample: 20132017

Periods included: 5

Cross-sections included: 7

Total panel (balanced) observations: 35

Swamy and Arora estimator of component variances
Model (CEM) atau Fixed Effect Model (FEM). Pengujian ini dapat dilihat pada nilai Probabilitas (Prob.) Cross-section F dan Cross-section chi Square dengan hipotesis sebagai berikut:

H0 : Model mengikuti Common Effect

Model (CEM) jika Probabilitas cross-section F dan Cross-section chi-square $>\alpha(0,05)$

Ha : Model mengikuti Fixed Effect Model (FEM) jika Probabilitas crosssection $\mathrm{F}$ dan Cross-section chisquare $<\alpha(0,05)$. berikut:

Adapun hasil uji chow sebagai

\section{Hasil Uji Chow}

lundant Fixed Effects Tests

Prisquation: EQ01

\begin{tabular}{|c|c|c|c|c|c|c|c|}
\hline Variable & Coefficient & Std. Error & t-Statistic & $\begin{array}{l}\text { Proquation: EQ01 } \\
\text { cross-section fixed eff }\end{array}$ & & & \\
\hline C & 2.096787 & 2.128846 & 0.984941 & $0.37 \%$ & & & \\
\hline UP & -4.649268 & 7.030785 & -0.661273 & 0.5EEffects Test & Statistic & d.f. & Prob. \\
\hline SM & 0.077529 & 0.148063 & 0.523623 & 0.645 & & & \\
\hline LIKUIDITAS & 0.089542 & 0.041931 & 2.135482 & 0.04 ross-section F & 4.286367 & $(6,23)$ & 0.0048 \\
\hline IOS & 0.000146 & 0.000251 & 0.581578 & 0.5650 ss-section Chi-square & 26.269549 & 6 & 0.0002 \\
\hline PROFITABILITAS & -0.949073 & 0.644758 & -1.471984 & $0.1 \div$ & & & \\
\hline
\end{tabular}

Sumber: Hasil Olahan Eviews 9.0, 2018

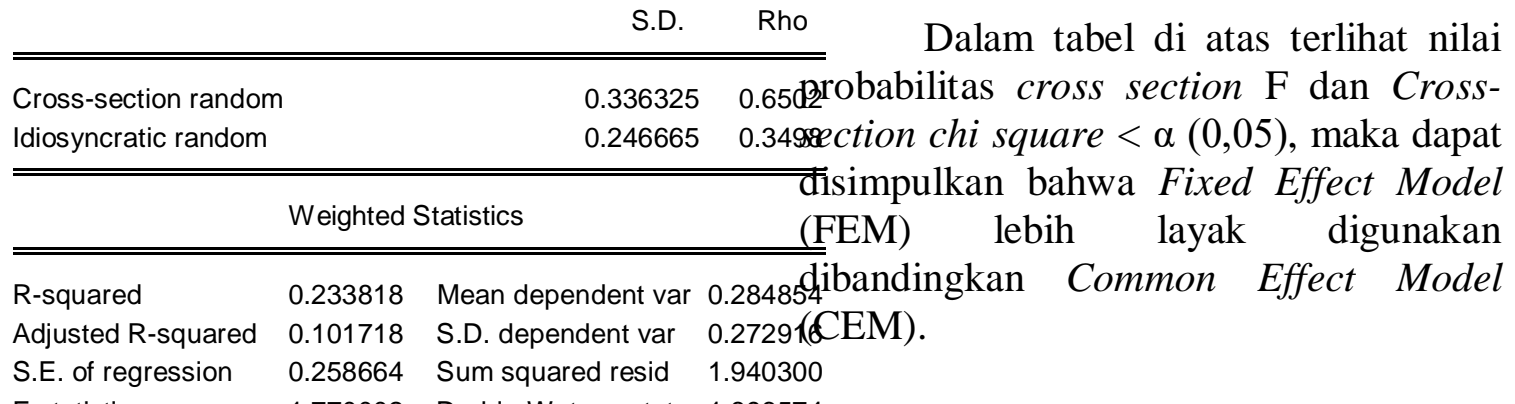

F-statistic 1.770002 Durbin-Watson stat 1.89657 ji Hausman

Prob(F-statistic) $0.150451 \quad$ Uji hausman digunakan untuk

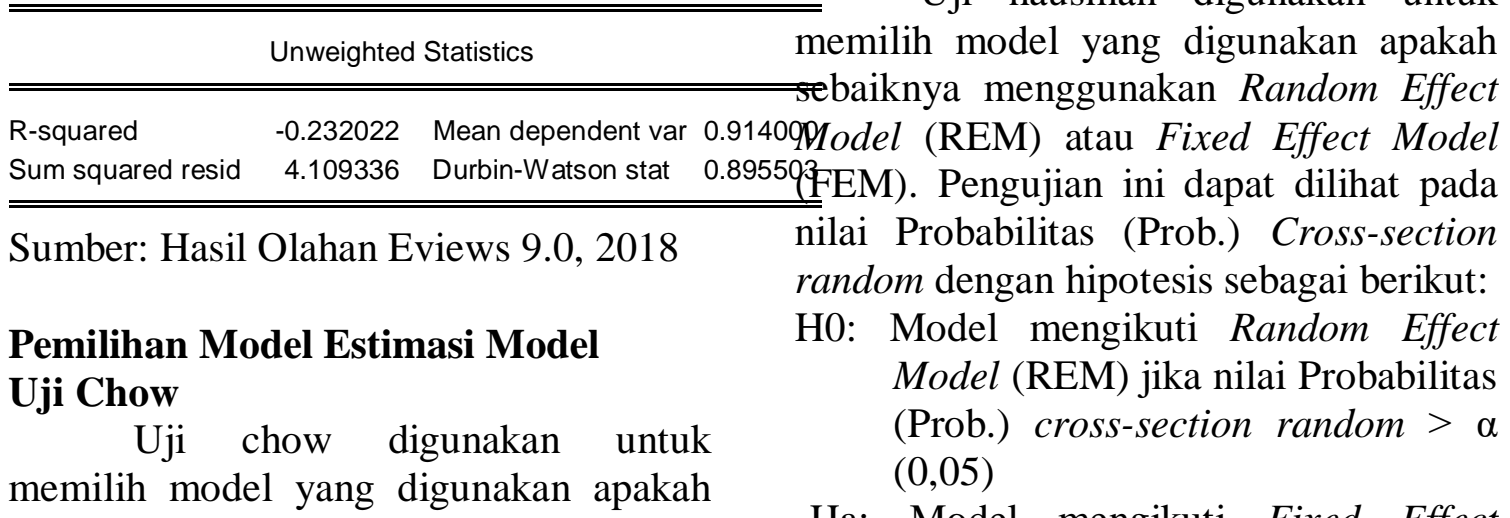
sebaiknya menggunakan Common Effect

Ha: Model mengikuti Fixed Effect Model (FEM) jika nilai Probabilitas 
Lagrange Multiplier Tests for Random Effects Null hypotheses: No effects

Alternative hypotheses: Two-sided (Breusch-Pagan) and one-sided

(all others) alternatives

\begin{tabular}{llll}
\hline \hline \multicolumn{3}{c}{ Test Hypothesis } \\
& Cross-section & Time & Both \\
\hline \hline Breusch-Pagan & $\begin{array}{l}1.347031 \\
(0.2458)\end{array}$ & $\begin{array}{l}0.933050 \\
(0.3341)\end{array}$ & $\begin{array}{l}2.280081 \\
(0.1310)\end{array}$
\end{tabular}

(Prob.) cross-section random $<\alpha$ $(0,05)$ berikut:

Adapun hasil uji hausman sebagai

\section{Hasil Uji Hausman}

Correlated Random Effects - Hausman Test

Equation: EQ01

Test cross-section random effects
Adapun hasil uji Langrange Multiplier sebagai berikut:

\section{Hasil Uji Langrange Multiplier}

Sumber: Hasil Olahan Eviews 9.0, 2018

Berdasarkan hasil perhitungan diatas nilai probabilitas Cross-section Breusch -pagan $>\alpha(0,05)$, maka dapat disimpulkan bahwa Cem Effect Model (CEM) lebih layak digunakan dibandingkan Random effect Model (REM).

\section{Kesimpulan Model}

Hasil pengujian disajikan dalam tā̄el sebagai berikut:

Test Summary Statistic Chi-Sq. d.f. Prob.

\begin{tabular}{|c|c|c|c|c|}
\hline Cross-section random & $0.1 \$ 8 d$. & Metode & Pengujian & Hasil \\
\hline \multirow{3}{*}{$\begin{array}{l}\text { Sumber: Hasil Olahan Eviews 9.0, } 2018 \\
\text { Dalam tabel di atas terlihat nilai } \\
\text { probabilitas cross section random > a } \\
(0,05) \text {, maka dapat disimpulkan bahwa } \\
\text { Random Effect Model (REM) lebih layak } \\
\text { digunakan dibandingkan Fixed Effect } \\
\text { Model (FEM). }\end{array}$} & $\overline{\bar{T}}$ & Uji Chow & $\begin{array}{l}\text { CEM vs } \\
\text { FEM }\end{array}$ & FEM \\
\hline & 2 & $\begin{array}{l}\text { Uji } \\
\text { Hausman }\end{array}$ & $\begin{array}{l}\text { REM vs } \\
\text { FEM }\end{array}$ & REM \\
\hline & 3 & $\begin{array}{l}\text { Uji } \\
\text { Langrange } \\
\text { Multiplier }\end{array}$ & $\begin{array}{l}\text { CEM vs } \\
\text { REM }\end{array}$ & CEM \\
\hline
\end{tabular}

\section{Uji Lagrange Multiplier}

Uji Langrange Multiplier digunakan untuk memilih model yang digunakan apakah sebaiknya menggunakan Commond Effect Model (CEM) atau Random Effect Model (REM). Pengujian ini dapat dilihat pada nilai Probabilitas Breush-pagan dengan hipotesis sebagai berikut:

H0 : Model mengikuti Commond Effect Model (CEM) jika nilai Probabilitas cross-section Breush-pagan $>\alpha$ $(0,05)$

Ha : Model mengikuti Random Effect Model (REM) jika ka nilai Probabilitas cross-section Breushpagan $<\alpha(0,05)$.
Menurut Basuki dan Prawoto (2016) secara formal ada tiga prosedur pengujian estimasi data panel, yaitu uji statistik $\mathrm{F}$ yang digunakan untuk memilih antara:

1) Model common effects atau fixed effects

2) Uji Langrange Multiplier (LM) yang digunakan untuk memilih antara model common effects atau model random effects

3) Uji Hausman yang digunakan untuk memilih antara model fixed effects atau model random effects

Dengan konsep demikian, apabila data OLS sudah dilakukan uji dengan uji chow maka hasilnya akan diuji lagi untuk 
menentukan data OLS atau GLS yang digunakan.

Berdasarkan hasil pengujian yang sudah dilakukan diketahui bahwa pada uji chow terpilih model FEM dengan nilai cross-section $f$ sebesar 0,0048 lebih kecil dari 0,05 dan pada uji hausman model yang terpilih adalah estimasi model REM dengan nilai cross section random sebesar 0,1624 lebih besar dari 0,05. Maka model yang digunakan adalah model Random Effect Model (REM).

\section{Uji Hipotesis}

\section{Uji $\mathbf{R}^{2}$ (Koefisien determinasi)}

Koefisien Determinasi merupakan cara untuk mengukur ketepatan suatu garis regresi. Menurut Gujarati (2001) bahwa koefisien determinasi yaitu angka yang menunjukkan besarnya derajat kemampuan menerangkan variabel bebas terhadap terikat dari fungsi tersebut. Hal tersebut dilakukan dengan cara pengukuran ketepatan suatu garis regresi dengan $\mathrm{R}^{2}$ yaitu angka yang menunjukkan besarnya derajat kemampuan menerangkan variabel bebas $\left(0<\mathrm{R}^{2}<1\right)$, dimana semakin mendekati 1 maka semakin dekat pula hubungan antar variabel bebas dengan variabel terikat atau dapat dikatakan bahwa model tersebut baik, demikian pula sebaliknya. determinasi:

Berikut hasil koefisien

\section{Hasil Uji Koefisien Determinasi}

\begin{tabular}{l|l} 
R-squared & 0,233818
\end{tabular}

Hasil $R$-Squared pada model ini adalah 0,233818 artinya bahwa variasi perubahan naik turunnya Kualitas Laba dapat dijelaskan oleh Ukuran Perusahaan, Struktur Modal, Likuiditas, Investment Opportunity Set, dan Profitabilitas sebesar $233.81 \%$, sedangkan sisanya $133.81 \%$ disebabkan oleh variabel atau hal lain diluar dari variabel yg diteliti.

\section{Uji t Parsial}

Uji Parsial bertujuan untuk menguji pengaruh masing-masing variabel independen terhadap variabel dependen. Dari hasil uji t parsial dapat dilihat dari nilai masing-masing probabilitas tiap variabel.

$$
\text { Rumusan hipotesis yang }
$$
digunakan dalam uji $\mathrm{F}$ adalah sebagai berikut:

1) Berdasarkan perbandingan $F$-statistic dengan $F$ Tabel

$\mathrm{HO}:$ Jika nilai $t$-statistic $<\mathrm{t}$ tabel

$\mathrm{Ha}:$ Jika nilai $t$-statistic $>\mathrm{t}$ tabel

Jika $t$-statistic $<\mathrm{t}$ tabel, maka $\mathrm{H} 0$

diterima yang artinya variabel independen (X) secara parsial tidak berpengaruh terhadap variabel dependen (Y). Namun sebaliknya, jika t-statistic $>\mathrm{t}$ tabel, maka Ha diterima artinya variabel independen $(\mathrm{X})$ secara parsial berpengaruh terhadap variabel dependen (Y).

2) Berdasarkan Probabilitas

H0 : Jika nilai Prob. $>\alpha 0,05$

Ha : Jika nilai Prob. $<\alpha 0,05$

Jika nilai Prob. $>\alpha$ 0,05, maka H0 diterima yang artinya variabel independen $(\mathrm{X})$ secara parsial tidak berpengaruh terhadap variabel dependen (Y). namun sebaliknya, Jika nilai Prob. $<\alpha 0,05$, maka Ha diterima artinya variabel independen (X) secara parsial berpengaruh terhadap variabel dependen (Y).

Berikut hasil dari uji t:

\section{Uji t (parsial)}




$\begin{array}{crrrr}\text { UP } & -4.649268 & 7.030785 & -0.661273 \\ \text { SM } & 0.077529 & 0.148063 & 0.523623 \\ \text { LIKUIDITAS } & 0.089542 & 0.041931 & 2.135482 \\ \text { IOS } & 0.000146 & 0.000251 & 0.581578 \\ \text { PROFITABILITAS } & -0.949073 & 0.644758 & -1.471984\end{array}$

Berdasarkan hasil uji $\mathrm{t}$ pada analisis resgresi panel menunjukan, maka dapat disimpulkan hasil hipotesis sebagai berikut:

1. Pengujian hipotesis pertama (H1)

Nilai t-statistic Ukuran Perusahaan sebesar -0,661, sementara $\mathrm{t}$ tabel dengan tingkat $\alpha=$ $5 \%$, df $(n-k)=35-5$ didapat nilai $\mathrm{t}$ tabel sebesar 2,042. Dengan demikian t-statistic Ukuran Perusahaan $(-0,661)<(2,042)$ dan nilai Prob. 0,5137>0,05 maka dapat disimpulkan bahwa variabel ukuran perusahaan dalam penelitian ini tidak memiliki pengaruh terhadap kualitas laba.

2. Pengujian hipotesis kedua $(\mathrm{H} 2)$

Nilai t-statistik struktur modal sebesar 0,523 sementara $\mathrm{t}$ tabel dengan tingkat $\alpha=5 \%$, df $(\mathrm{n}-\mathrm{k})=35$ 5 didapat nilai t tabel sebesar 2,042. Dengan demikian t-statistic struktur modal $(0,523)<(2,042)$ dan nilai Prob. 0,6045>0,05 maka dapat disimpulkan bahwa variabel struktur modal dalam penelitian ini tidak memiliki pengaruh terhadap kualitas laba.

3. Pengujian hipotesis ketiga (H3)

Nilai t-statistik likuiditas sebesar 2,135 sementara $\mathrm{t}$ tabel dengan tingkat $\alpha=5 \%$, df (n-k) $=35-5$ didapat nilai t tabel sebesar 2,042. Dengan demikian t-statistic likuiditas $(2,135)>(2,042)$ dan nilai Prob. $0,0413<0,05$ maka dapat disimpulkan bahwa variabel likuiditas dalam penelitian ini memiliki pengaruh terhadap kualitas laba.

4. Pengujian hipotesis keempat (H4)
0. Wiikza t-statistik IOS sebesar 0,581 0.6045 entara $\mathrm{t}$ tabel dengan tingkat $\alpha=$ 0.0413
0.5653 df $(\mathrm{n}-\mathrm{k})=35-5$ didapat nilai $\mathrm{t}$ 0.trabar sebesar 2,042. Dengan t-statistic IOS $(0,581)<$ $(2,042)$ dan nilai Prob. $0,5653>0,05$ maka dapat disimpulkan bahwa variabel struktur modal dalam penelitian ini tidak memiliki pengaruh terhadap kualitas laba.

5. Pengujian hipotesis kelima (H5)

Nilai t-statistik Profitabilitas sebesar $-1,472$ sementara $\mathrm{t}$ tabel dengan tingkat $\alpha=5 \%$, df $(\mathrm{n}-\mathrm{k})=35-5$ didapat nilai t tabel sebesar 2,042. Dengan demikian t-statistik profitabilitas $(-1,472)<(2,042)$ dan nilai Prob. 0,1518>0,05 maka dapat disimpulkan bahwa variabel profitabilitas dalam penelitian ini tidak memiliki pengaruh terhadap kualitas laba.

\section{Persamaan Model Regresi Data} Panel

Fungsi persamaan regresi adalah untuk memprediksi nilai variabel dependen (Y) dan untuk mengetahui arah dan besarnya pengaruh variabel independen (X) terhadap variabel dependen $(\mathrm{Y})$. diperoleh :

Berikut nilai coefficient yang

Tabel 4.29

Nilai Coefficient

\begin{tabular}{|c|c|}
\hline Variabel & Coefficient \\
\hline C & 2.096787 \\
\hline UP & -4.649268 \\
\hline SM & 0.077529 \\
\hline LIKUIDITAS & 0.089542 \\
\hline IOS & 0.000146 \\
\hline PROFITABILITAS & -0.949073 \\
\hline
\end{tabular}

Hasil persamaan regresi yang diperoleh adalah :

$\mathrm{Y}=2,096787-4,649268 \mathrm{UP}+0,077529 \mathrm{SM}+$ 0,089542 LIKUIDITAS $+0,000146$ IOS $-0,949073$ PROFITABILITAS + e 
Persamaan regresi diatas memiliki makna sebagai berikut:

a. Konstanta 2,096 (209,6\%) menyatakan bahwa jika variabel independen dianggap konstan, maka kualitas laba yang terjadi adalah sebesar $2,096(209,6 \%)$

b. Ukuran Perusahaan mempunyai koefisien regresi kearah negatif sebesar $-4,649$ (464,9\%). Hal ini berarti semakin kecil ukuran suatu perusahaan, maka kualitas labanya akan semakin rendah. Artinya semakin kecil ukuran suatu perusahaan maka kualitas labanya semakin rendah sehingga perusahaan yang relatif besar memiliki kualitas laba yang lebih tinggi daripada perusahaan kecil.

c. Struktur modal mempunyai koefisien regresi kearah positif sebesar $0,077(7,7 \%)$. Hal ini berarti semakin kecil leverage suatu perusahaan maka kualitas labanya akan semakin besar. Artinya jika perusahaan memiliki utang yang rendah maka manajemen perusahaan akan termotivasi untuk memanipulasi laba dengan memperbesar laba perusahaan sehingga dapat menunjukkan laba yang berkualitas.

d. Likuiditas mempunyai koefisien regresi kearah positif sebesar 0,089 (8,9\%). Hal ini berarti semakin kecil likuiditas suatu perusahaan, maka kualitas labanya akan semakin tinggi. Artinya jika perusahaan memiliki likuiditas yang tinggi maka manajemen perusahaan akan memanipulasi laba.

e. Investment Opportunity Set mempunyai koefisien regresi kearah positif sebesar $0,000146(0,00146 \%)$. Hal ini berarti semakin kecil IOS suatu perusahaan, maka kualitas labanya akan semakin rendah. Artinya jika perusahaan memiliki IOS yang rendah maka manajemen perusahaan akan termotivasi untuk memanipulasi laba dengan memperbesar laba perusahaan sehingga dapat menunjukkan laba yang berkualitas.

f. Profitabilitas mempunyai koefisien kearah negative sebesar -0,949 (94,9\%). Hal ini berarti semakin kecil profitabilitas suatu perusahaan, maka kualitas labanya akan semakin rendah. Artinya jika perusahaan memiliki profitabilitas yang tinggi maka kualitas labanya akan lebih besar disbanding perusahaan yang mempunyai profitabilitas rendah.

\section{Interpretasi Hasil}

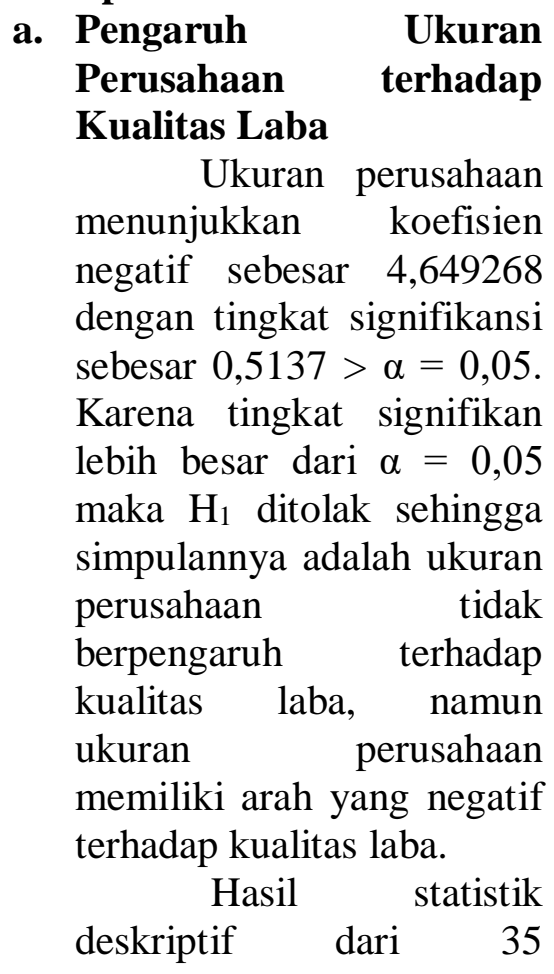


perusahaan yang diteliti menunjukkan bahwa ratarata jumlah ukuran perusahaan sebesar 29,06\%, sedangkan prosentase tertinggi dari rasio total aset tetap sebesar $32 \%$ dan nilai terendahnya sebesar 26\%. Semakin kecil ukuran suatu perusahaan memiliki kualitas laba yang lebih tinggi daripada perusahaan kecil. Perusahaan yang relatif kecil kinerjanya tidak akan terlalu dilihat oleh publik sehingga perusahaan tersebut akan melaporkan kondisi keuangannya dengan lebih leluasa, maka akan rentan menunjukkan keinformatifan informasi yang terkandung di dalamnya dan kurang transparan sehingga akan lebih banyak dalam melakukan manipulasi laba (Warianto dan Rusiti; 2014).

Hasil penelitian sejalan dengan penelitian yang dilakukan oleh Wati \& Putra (2017) yang menyatakan bahwa ukuran perusahaan tidak berpengaruh terhadap kualitas laba. Namun penelitian ini tidak sejalan dengan penelitian yang dilakukan oleh Dira \& Astika (2014) yang menyatakan bahwa ukuran perusahaan berpengaruh positif terhadap kualitas laba.

b. Pengaruh Struktur Modal terhadap Kualitas Laba modal $\begin{array}{r}\text { Variabel struktur } \\ \text { menunjukkan }\end{array}$ koefisien positif sebesar 0,077 dengan tingkat signifikan sebesar 0,6045 > dari $\alpha=0,05$. Karena tingkat signifikan lebih besar dari $\alpha=0,05$ maka $\mathrm{H}_{2}$ ditolak sehingga simpulannya adalah struktur modal tidak berpengaruh terhadap kualitas laba, namun struktur modal memiliki arah yang positif terhadap kualitas laba.

Struktur modal biasanya diukur leverage karena untuk mengetahui seberapa besar aset perusahaan yang dibiayai oleh hutang perusahaan. Perusahaan yang memiliki hutang tinggi dapat berdampak pada risiko keuangan yang semakin besar yaitu kemungkinan perusahaan tidak mampu membayar utang-utangnya. Adanya risiko gagal bayar ini menyebabkan biaya yang harus dikeluarkan perusahaan untuk mengatasi hal tersebut semakin besar sehingga akan menurunkan laba perusahaan. Oleh karena itu, jika tingkat leverage suatu perusahaan tinggi maka akan memiliki kecenderungan untuk melakukan manipulasi laba yang besar sehingga kualitas laba yang dihasilkan menjadi rendah (Silfi;2016).

Hasil penelitian ini sejalan dengan penelitian yang dilakukan oleh Irawati (2012) yang menunjukkan bahwa struktur modal tidak 
berpengaruh terhadap
kualitas laba, namun
penelitian ini $\begin{array}{r}\text { tidak } \\ \text { didukung oleh penelitian }\end{array}$
yang dilakukan oleh Silfi
(2016) yang menunjukkan
bahwa struktur modal
berpengaruh terhadap
kualitas laba.

c. Pengaruh Likuiditas terhadap Kualitas Laba

Variabel likuiditas

menunjukkan koefisien

positif sebesar 2,135

dengan tingkat signifikan sebesar $0,0413<$ dari $\alpha=$ 0,05. Karena tingkat signifikan lebih kecil dari $\alpha$ $=0,05$ maka $\mathrm{H}_{3}$ di terima. Penelitian ini berhasil membuktikan adanya pengaruh likuiditas terhadap kualitas laba, koefisien regresi bernilai positif.

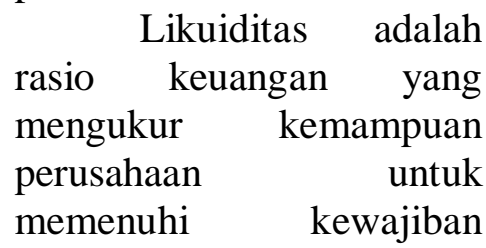
jangka pendek dengan aset lancarnya. Rasio likuiditas yang umum digunakan adalah current ratio. Current ratio yang tinggi biasanya dianggap menunjukkan tidak terjadi masalah dalam likuiditas, sehingga semakin tinggi likuiditas artinya laba yang dihasilkan suatu perusahaan berkualitas karena manajemen perusahaan tidak perlu melakukan praktik manipulasi laba (Silfi; 2016).

Hasil penelitian ini sejalan dengan penelitian yang dilakukan oleh Silfi
(2016) yang menunjukkan bahwa likuiditas berpengaruh terhadap kualitas laba, namun penelitian ini tidak didukung oleh penelitian yang dilakukan oleh Warianto \& Rusiti (2014) yang menunjukkan bahwa likuiditas berpengaruh negatif terhadap kualitas laba.

d. Pengaruh Investment Opportunity Set terhadap Kualitas Laba

$$
\text { Variabel IOS }
$$

menunjukkan koefisien

positif sebesar 0,000146 dengan tingkat signifikan sebesar $0,5653>$ dari $\alpha=$ 0,05 . Karena tingkat signifikan lebih besar dari $\alpha$ $=0,05$ maka $\mathrm{H}_{4}$ ditolak sehingga simpulannya adalah investment opportunity set tidak berpengaruh terhadap kualitas laba, namun investment opportunity set memiliki arah positif terhadap kualitas laba. Jaya dan Wirama (2017) menyatakan bahwa perusahaan dengan tingkat pertumbuhan yang tinggi juga memiliki motivasi untuk meminimalkan laba. Ketika perusahaan memiliki IOS yang tinggi maka nilai perusahaan akan meningkat karena lebih banyak investor yang tertarik untuk berinvestasi dengan harapan memperoleh return yang lebih besar di masa yang akan datang, menyebabkan adanya kemungkinan manajemen perusahaan 
melakukan manipulasi laba karena untuk mempertahankan pertumbuhan perusahaan. Hasil penelitian ini tidak sejalan dengan penelitian yang dilakukan oleh Jaya dan Wirama (2017) yang menyatakan bahwa investment opportunity set berpengaruh negatif terhadap kualitas laba.

e. Pengaruh Profitabilitas terhadap Kualitas Laba Variabel

profitabilitas menunjukkan koefisien negatif sebesar 0,949073 dengan tingkat signifikan sebesar $0,1518>$ $\alpha=0,05$. Karena tingkat signifikan lebih besar dari $\alpha$ $=0,05$ maka $\mathrm{H}_{5}$ ditolak. Penelitian ini berhasil membuktikan tidak adanya pengaruh profitabilitas terhadap kualitas laba, koefisien regresi bernilai negatif.

\begin{tabular}{lrr}
\multicolumn{4}{r}{ Profitabilitas } & adalah \\
rasio keuangan & yang \\
mengukur & kemampuan \\
perusahaan & \multicolumn{1}{r}{ dalam } \\
menghasilkan & laba & dan \\
memanfaatkan & aktiva yang \\
dimilikinya. & Rasio \\
profitabilitas & yang \\
umumnya & digunakan \\
adalah Return On & Asset \\
(ROA). Semakin & besar \\
return on asset & (ROA) \\
suatu perusahaan, & semakin \\
besar pula & tingkat \\
keuntungan yang & dicapai \\
oleh perusahaan. & Tanpa \\
adanya keuntungan & akan \\
sangat & sulit & bagi \\
perusahaan untuk & menarik \\
modal dari luar. Perusahaan
\end{tabular}

dengan profitabilitas tinggi juga mempunyai koefisien respon laba yang lebih besar dibanding dengan perusahaan yang mempunyai profitabilitas rendah. Artinya ketika perusahaan memiliki keuntungan yang tinggi investor tertarik untuk melakukan investasi (Kasmir; 2015).

Hasil penelitian ini sejalan dengan penelitian yang dilakukan oleh Anjelica dan Praetyawan (2017) yang menunjukkan bahwa profitabilitas tidak berpengaruh terhadap kualitas laba, namun penelitian ini tidak didukung oleh penelitian Risdawaty \& Subowo (2015) yang menyatakan bahwa Profitabilitas berpengaruh negatif terhadap kualitas laba.

\section{KESIMPULAN DAN SARAN}

\section{Kesimpulan}

A. Kesimpulan

Penelitian ini memiliki tujuan untuk mengetahui pengaruh ukuran perusahaan, struktur modal, likuiditas, investment opportunity set, dan profitabilitas terhadap kualitas laba dengan menggunakan perusahaan makanan dan minuman yang terdaftar di Bursa Efek Indonesia yang terdaftar dari tahun 2013-2017 sebagai objek penelitian dengan total sampel sebanyak 7 perusahaan dari total 18 populasi perusahaan, dan analisis menggunakan regresi data panel.

Berdasarkan hasil analisis data yang dilakukan pada bab empat, 
maka dapat hasil yang diperoleh dapat disimpulkan sebagai berikut;

1. Ukuran Perusahaan memiliki nilai t-statistik $(-4,649)<\mathrm{t}$-tabel $(-2,042)$ dan nilai prob. $0,5137>$ 0,05 maka ukuran perusahaan berpengaruh negatif dan tidak signifikan terhadap kualitas laba bahwa semakin kecil ukuran suatu perusahaan, maka kualitas labanya akan semakin tinggi. Artinya semakin kecil ukuran suatu perusahaan maka kualitas labanya semakin tinggi sehingga perusahaan yang relative besar memiliki kualitas laba yang lebih rendah daripada perusahaan kecil.

2. Struktur Modal memiliki nilai $t$ statistic sebesar $(0,077)<\mathrm{t}$-tabel $(2,042)$ dan nilai prob. $0,6045>$ 0,05 maka struktur modal tidak berpengaruh terhadap kualitas laba, namun struktur modal memiliki arah yang positif terhadap kualitas laba. Hal ini berarti semakin kecil leverage suatu perusahaan maka kualitas labanya akan semakin besar. Artinya jika perusahaan melakukan utang yang rending maka manajemen perusahaan akan termotivasi untuk memanipulasi laba dengan memperbesar laba perusahaan sehingga dapat menunjukkan laba yang berkualitas.

3. Likuiditas memiliki nilai $t$ statistic sebesar $(2,135)>\mathrm{t}$-tabel $(2,042)$ dan nilai prob. $0,0413>$ 0,05 maka dapat disimpulkan bahwa likuiditas berpengaruh terhadap kualitas laba karena semakin kecil likuiditas suatu perusahaan, maka kualitas labanya akan semakin tinggi. Artinya jika perusahaan memiliki likuiditas yang tinggi maka manajemen perusahaan akan memanipulasi laba.

4. Investment Opportunity Set memiliki nilai t-statistik sebesar $(0,000146)<(2,042)$ dan nilai prob. 0,5653>0,05 maka dapat disimpulkan bahwa investment opportunity set tidak berpengaruh terhadap kualitas laba karena semakin kecil investment opportunity set suatu perusahaan, maka kualitas labanya akan semakin rendah. Artinya jika perusahaan memiliki investment opportunity set yang rendah maka manajemen perusahaan akan termotivasi untuk memanipulasi laba dengan memperbesar laba perusahaan sehingga dapat menunjukkan laba yang berkualitas.

5. Profitabilitas memiliki nilai $t$ statistic $(0,949)<(2,042)$ dan nilai Prob. 0,1518>0,05 maka dapat disimpulkan bahwa profitabilitas tidak berpengaruh terhadap kualitas laba bahwa semakin kecil profitabilitas suatu perusahaan maka kualitas labanya akan semakin rendah. Artinya jika perusahaan memiliki profitabilitas yang tinggi maka kualitas labanya akan lebih besar dibanding perusahaan yang mempunyai profitabilitas rendah.

B. Keterbatasan

Beberapa keterbatasan dalam penelitian ini adalah sebagai berikut:

1. Penelitian ini hanya menggunakan perusahaan manufaktur sektor makanan dan minuman sebagai objek penelitian dan tidak mengikutsertakan sektor lain.

2. periode pengamatan dalam penelitian ini sangat singkat 
memiliki rentang waktu 5 tahun dari tahun 2013-2017.

\section{Rekomendasi}

Penelitian ini di masa mendatang diharapkan dapat menyajikan hasil penelitian yang lebih berkualitas lagi dengan adanya beberapa masukan mengenai beberapa hal diantaranya sebagai berikut:

a. Saran Teoritis

Penelitian ini diharapkan dapat memberikan pengetahuan serta wawasan yang lebih luas mengenai kualitas laba, hasil penelitian dan ilmu yang berkaitan dengan materi selama masa perkuliahan yang terdapat dalam penelitian ini.

b. Saran Praktis

i. Bagi perusahaan,

Diharapkan dapat memberikan manfaat bahwa pentingnya memberikan informasi laba yang berkualitas terhadap investor. Dan seberapa besar pengaruh ukuran perusahaan, struktur modal, likuiditas, investment opportunity set terhadap kualitas laba.

ii. Bagi calon investor,

Diharapkan dapat menjadi suatu sarana pertimbangan bagi calon investor untuk menetapkan pilihan investasi yang tepat, sehingga bisa memperoleh keuntungan dan menghindari resiko.

iii. Bagi akademik, Diharapkan dapat digunakan sebagai bahan informaqsi dan sumbangan ilmu pengetahuan untuk penelitian lebih lanjut di masa yang datang khususnya tentang akuntansi keuangan.

\section{DAFTAR PUSTAKA}

Anjelica dan Prasetyawan. 2014. Pengaruh Profitabilitas, Umur Perusahaan, Ukuran Perusahaan, Kualitas Audit, dan Struktur Modal Terhadap Kualitas Laba. Ultima Accounting Vol. 6 No. 14

Alwi, Z Iskandar. 2003. Pasar Modal: Teori dan Aplikasi. Jakarta: Nasindo Internusa.

Brigham, Eugene F. dan Joel F. Houston. 2006. Dasar-dasar Manajemen Keuangan. Jakarta: Salemba Empat.

Dira dan Astika. 2014. Pengaruh struktur modal, Likuiditas, Pertumbuhan Laba, dan Ukuran perusahaan terhadap Kualitas Laba. EJurnal Akuntansi Universitas Udayana Vol.7 No.1.

Eksandy, Arry. 2018. Pedoman Penulisan Skripsi Prodi Akuntansi. Universitas Muhammadiyah Tangerang.

Irawati, Dhian Eka. 2012. Pengaruh Struktur Modal, Pertumbuhan Laba, Ukuran Perusahaan Dan Likuiditas Terhadap Kualitas Laba. Accounting Analysis Journal. Vol. 1 No. 2

Jaya dan Wirama. 2017. Pengearuh Investment Opportunity Set, Likuiditas, dan Ukuran Perusahaan pada Kualitas Laba. E-Jurnal Akuntansi Universitas Udayana Vol.21 No.3

Risdawaty, Iin Mutmainah Eka dan Subowo Subowo. 2015. Pengaruh Struktur Modal, 
Ukuran Perusahaan, Asimetri Informasi, dan Profitabilitas terhadap Kualitas Laba. Jurnal Dinamika Akuntansi Vol 7, No 2

Silfi. 2016. Pengaruh Pertumbuhan Laba, Struktur Modal, Likuiditas, dan Komite Audit terhadap Kualitas Laba. Valuta Jurnal Administrasi Bisnis, Manajemen, dan Ekonomi. Vol. 2 No. 1

Sugiyono. 2017. Metode Penelitian Kuantitatif, Kualitatif dan $R \& D$. Bandung: Alfabeta.

Warianto dan Rusiti. 2014. Pengaruh Ukuran Perusahaan, Struktur Modal, Likuiditas, dan Investmenr Opportunity Set (IOS) terhadap Kualitas Laba. Modus Journals. Vol. 26 No. 1.

Wardiyah, Mia Lasmi. 2017. Manajemen Pasar Uang \& Pasar Modal. Bandung: Pustaka Setia.

Wati dan Putra. 2017. Pengaruh Ukuran Perusahaan, Leverage, dan Good Corporate Governance pada Kualitas Laba. E-Jurnal Akuntansi Universitas Udayana Vol.19 No.1.

Winarno, Wing Wahyu. 2017. Analisis Ekonometrika dan Statistika dengan Eviews.

Yogyakarta: STIM YKPN.

Yushita, Rahmawati, dan Traitmoko. 2013. Pengaruh mekanisme Corporate Governance, Kualitas Auditor Eksternal, dan Likuiditas terhadap Kualitas Laba. Jurnal Economia. Vol 9 No.2. www.idx.co.id (Senin, 11 Juni 2018)

www.investasi.kontan.co.id (Kamis, 19 April 2018)

www.katadata.co.id (Kamis, 19 April 2018)

www.bareksa.com (Jum'at, 20 April 2018)

www.cnnindonesia.com (Jum'at, 20 April 2018) 